\title{
zona de sombra
}

ERO mi alma busca un espacio libre para su salto mortal 1.0. y huye multiplicada en las vidrieras que la absorben mezclándola a la vida fisica de la ciudad en el fondo de sus espejos infinitos restalla tu látigo alegria frenética de evadirse desorganizada danza sobre los terciopelos su danza jovial libre sin conceptos anteriores resbala sobre los vidrios de los automóviles en marcha sube hasta donde corren los vientos que traen la noche en sus [trapecios y desciende zumbando como una piedra en el aire caliente libértate gira oh alma en tu espiral de espacio afirmado en las paredes mi canto de hombre te acompaña con su acordeón agujereado y triste 